\title{
Intraspecific Variation in Wood Anatomical, Hydraulic, and Foliar Traits in Ten European Beech Provenances Differing in Growth Yield
}

\author{
Peter Hajek ${ }^{1}$, Daniel Kurjak ${ }^{2}$, Georg von Wühlisch ${ }^{3}$, Sylvain Delzon ${ }^{4}$ and \\ Bernhard Schuldt ${ }^{1 *}$ \\ ${ }^{1}$ Plant Ecology, Albrecht von Haller Institute for Plant Sciences, University of Göttingen, Göttingen, Germany, ${ }^{2}$ Faculty of \\ Forestry, Technical University in Zvolen, Zvolen, Slovakia, ${ }^{3}$ Federal Research Institute for Rural Areas, Forestry and Fisheries, \\ Thuenen Institute for Forest Genetics, Großhansdorf, Germany, ${ }^{4}$ UMR BIOGECO Institut National de la Recherche \\ Agronomique-UB, University of Bordeaux, Talence, France
}

OPEN ACCESS

Edited by:

Sergio Rossi,

Université du Québec à Chicoutimi,

Canada

Reviewed by:

Tommaso Anfodillo,

University of Padova, Italy Jordi Martínez-Vilalta,

Autonomous University of Barcelona,

Spain

*Correspondence:

Bernhard Schuldt

bernhard.schuldt@plant-ecology.de

Specialty section:

This article was submitted to

Functional Plant Ecology,

a section of the journal

Frontiers in Plant Science

Received: 28 February 2016

Accepted: 22 May 2016

Published: 15 June 2016

Citation:

Hajek P, Kurjak D, von Wühlisch $G$,

Delzon S and Schuldt B (2016)

Intraspecific Variation in Wood

Anatomical, Hydraulic, and Foliar

Traits in Ten European Beech Provenances Differing in Growth Yield.

Front. Plant Sci. 7:791.

doi: 10.3389/fpls.2016.00791
In angiosperms, many studies have described the inter-specific variability of hydraulic-related traits and little is known at the intra-specific level. This information is however mandatory to assess the adaptive capacities of tree populations in the context of increasing drought frequency and severity. Ten 20-year old European beech (Fagus sylvatica L.) provenances representing the entire distribution range throughout Europe and differing significantly in aboveground biomass increment (ABI) by a factor of up to four were investigated for branch wood anatomical, hydraulic, and foliar traits in a provenance trial located in Northern Europe. We quantified to which extend xylem hydraulic and leaf traits are under genetic control and tested whether the xylem hydraulic properties (hydraulic efficiency and safety) trades off with yield and wood anatomical and leaf traits. Our results showed that only three out of 22 investigated ecophysiological traits showed significant genetic differentiations between provenances, namely vessel density (VD), the xylem pressure causing $88 \%$ loss of hydraulic conductance and mean leaf size. Depending of the ecophysiological traits measured, genetic differentiation between populations explained $0-14 \%$ of total phenotypic variation, while intra-population variability was higher than inter-population variability. Most wood anatomical traits and some foliar traits were additionally related to the climate of provenance origin. The lumen to sapwood area ratio, vessel diameter, theoretical specific conductivity and theoretical leaf-specific conductivity as well as the C:N-ratio increased with climatic aridity at the place of origin while the carbon isotope signature $\left(\delta^{13} \mathrm{C}\right)$ decreased. Contrary to our assumption, none of the wood anatomical traits were related to embolism resistance but were strong determinants of hydraulic efficiency. Although $A B I$ was associated with both VD and $\delta^{13} \mathrm{C}$, both hydraulic efficiency and embolism resistance were unrelated, disproving the assumed trade-off between hydraulic efficiency and safety. European beech seems to compensate increasing water stress with growing size mainly by 
adjusting vessel number and not vessel diameter. In conclusion, European beech has a high potential capacity to cope with climate change due to the high degree of intra-population genetic variability.

Keywords: adaptive capacity, Fagus sylvatica L., genetic variability, hydraulic conductivity, leaf morphology, phenotypic plasticity, provenance trial, vulnerability to cavitation

\section{INTRODUCTION}

European beech (Fagus sylvatica L.) dominated the natural vegetation types of forests in Central Europe for centuries, forming large stands of resilient forest ecosystems (Ellenberg and Leuschner, 2010). Despite the competitive superiority of European beech for tree populations in temperate forests, this species is more vulnerable to drought-induced stem growth reductions than other temperate broad-leaved trees (Leuschner et al., 2001; Zimmermann et al., 2015). Consequently, the Central European beech populations are expected to suffer high mortality rates probably altering the distribution range at its dry distributional limit as a consequence of increased physiological stress due to a higher risk of drought exposure associated with recent climate change.

According to its large geographic distributional range, European beech is expected to exhibit substantial genetic diversity (Bolte et al., 2007). The inherent capability of this species to survive and reproduce successfully across such a wide range of habitats is either maintained by long-term adaptation (i.e., genotypic variation) or short-term acclimation (i.e., phenotypic plasticity; Lindner et al., 2010; Kremer et al., 2014). Consequently, evolutionary adaptation may have caused the selection of ecotypes adapted to the regional climatic conditions, which is manifested in phenotypic variation of plant functional traits across various provenances (Hamrick, 2004). Despite an increasing amount of studies on functional traits which are known to be related to drought resistance in beech, e.g., leaf stomatal features (Stojnić et al., 2015), wood structure (Eilmann et al., 2014), resistance to xylem cavitation (Herbette et al., 2010, Wortemann et al., 2011), or hydraulic architecture (Aranda et al., 2015; Schuldt et al., 2016), still very little information is available on the relevance of phenotypic plasticity or genetic variation of traits on the adaptation of populations.

The high trait plasticity and remarkable regeneration potential of beech trees after disturbance leads to the assumption that beech is able to bear water shortage to a certain degree (Kahle, 2006; van der Werf et al., 2007). However, other studies report on drought susceptibility or dramatic yield loss and regeneration periods of decades subsequent to drought events and there is still an ongoing debate on the response of beech populations to drought exposure (Leuschner et al., 2001; Peuke et al., 2002; Leuzinger et al., 2005; Bréda et al., 2006; Jump et al., 2006). The mechanisms behind the adaptation and adaptability of beech to drought is a main challenge for a better understanding of the effects of climate change on this economically and ecologically important tree species. Because productivity is closely coupled with hydraulic efficiency (Hajek et al., 2014; Hoeber et al., 2014; Kotowska et al., 2015) and may only be achieved at the cost of hydraulic safety (Cochard et al., 2007), genetic differentiation in wood anatomical and hydraulic traits should be most pronounced between provenances differing in yield. However, the way how different provenances of the same tree species cope with such trade-offs still remains poorly investigated.

The main objective of this study was to investigate the genetic differentiation in vulnerability to xylem embolism and other related hydraulic and foliar properties across ten European beech provenances differing in growth performance. We further aimed to investigate the relationships and potential trade-offs between hydraulic, wood anatomical and leaf traits within species. We hypothesized that (i) drought-related traits are under genetic control and therefore populations are locally adapted to their environment, (ii) hydraulic efficiency and embolism resistance are related to anatomical traits, and (iii) a high hydraulic efficiency leads to high growth rates at the cost of xylem safety.

\section{MATERIALS AND METHODS}

\section{Experimental Site, Plant Material, and Microclimatic Conditions at the Place of Origin}

The field trial studied is part of the International Beech Provenance Trial Series 1993/1995 under EU funding (AIR3CT94-2091), which investigates the role of the genetic variation of beech for adaptability, productivity and selected ecosystem functions considering risks of global climate change (von Wuehlisch et al., 1998). For the present study conducted in August 2014, the common-garden field trial with 100 different European beech (Fagus sylvatica L.) provenances established in 1995 in Northern Germany (Schleswig-Holstein) with 2year old saplings near the Schädtbek Experimental Farm (54 $18^{\prime} \mathrm{N}, 10^{\circ} 16^{\prime} \mathrm{E}, 40 \mathrm{~m}$ a.s.l.) was used. The climate at the site is oceanic, moderately cold with a mean annual temperature (MAT) of $8.3^{\circ} \mathrm{C}$, a mean annual precipitation (MAP) of 742 $\mathrm{mm}$ and a mean early growing season precipitation from April to June (MSP) of $149 \mathrm{~mm}$ (data obtained from the German Meteorological Service). The common garden trial consists of $10 \times 10 \mathrm{~m}$ plots planted with 50 beech saplings per provenance in a 3-times replicated randomized block design. The beech trees are arranged in a rectangular grid with a planting distance of $2 \mathrm{~m}$ between and $1 \mathrm{~m}$ within rows. The trial is surrounded by a single bordering tree row serving as buffer zone to avoid edge effects. As all provenances were grown in a single environment (common garden), we were able to assess the genetic differentiations between provenances for several functional traits. The common garden experienced no management operations since plantation establishment in 1995, resulting in competitive selection 
among tree individuals leading to heterogeneity in plot characteristics.

From the 100 available provenances, ten provenances differing in aboveground growth increment (Figure S1) were selected in order to cover not only a gradient in growth yield but also a climatic gradient at the place of origin (Figure S2). By this selection, we covered provenances from different geographic regions and climates throughout Europe with a broad range of MAT (3.4-15.3 ${ }^{\circ} \mathrm{C}$ ) and MAP (575-1080 mm; Table 1). Mean annual climate data from 1950 to 2000 at the place of origin for each of the ten provenances were obtained from the WorldClim database with 30 arc-seconds resolution (Hijmans et al., 2005). In order to estimate climate dryness at the place of origin, we used the WorldClim database to access the global aridity index (GAI, Zomer et al., 2008) and calculated the forest aridity index (FAI) according to Fuehrer et al. (2011) as FAI $=100 \times$ $T_{\text {Jul-Aug }} /\left(P_{\text {Mai-Jul }}+P_{\text {Jul-Aug }}\right)$, where $T$ is the temperature and $P$ the precipitation of the associated interval. Since the atmospheric evaporative demand in the growing season is highest in midsummer (July and August), the July precipitation was weighted by a factor of two in the denominator. We further calculated Ellenberg's climate quotient (EQ, Ellenberg and Leuschner, 2010) as $\mathrm{EQ}=\left(T_{\mathrm{Jul}} / P_{\text {annual }}\right) \times 1000$. All measures of water availability and climatic aridity at the places of provenance origin were highly interrelated (data not shown). We therefore decided to use the forest aridity index (FAI) as integrate variable for all subsequent analyses.

Provenances were selected according to differences in aboveground growth increment based on a tree inventory in January 2013 (Figure S1). Within a given provenance, ten tree individuals of comparable size close to the population average (diameter at breast height and tree height) were selected assuming uniform growth conditions (site conditions and intraspecific competition) and consequently representing the average growth increment of a given provenance, yielding 100 processed tree individuals in total. A 2- to 4-year-old branch segment (mean \pm SE : $2.25 \pm 0.05$ year) was collected in
August 2014 from the uppermost canopy of each selected tree individual with a long-reaching telescope pruner and recut to approximately $50 \mathrm{~cm}$ length on the ground. Selected segments were defoliated and immediately transferred to plastic tubes containing deionized water and Micropur (Katadyn, Wallisellen, Switzerland) to prevent microbial activity and stored at $4^{\circ} \mathrm{C}$ until further processing within 4 weeks. All leaves of the respective segments were stored separately for foliar analyses. A list of all measured traits, their symbols and units are given in Table 2.

\section{Timber Volume, Above-Ground Biomass, and Basal Area Increment}

Aboveground growth performance (i.e., stem increment and height growth) of the respective genotypes under the local environment was evaluated from diameter at breast height $(\mathrm{DBH}, \mathrm{cm})$ and tree height $(\mathrm{m})$. Aboveground productivity expressed as aboveground biomass increment (ABI, $\mathrm{kg} \mathrm{yr}^{-1}$ ) was calculated for the entire growth period (1995-2014), and basal area increment (BAI, $\mathrm{cm}^{2} \mathrm{yr}^{-1}$ ) from two inventories in January 2013 and August 2014, respectively. For calculating the volume of stems and branches of at least $7 \mathrm{~cm}$ in diameter (standing volume of timber), we used the allometric equation $V=\pi \times$ $((D / 100) / 2)^{2} \times H \times f$, where $V$ is the volume of timber $\left(\mathrm{m}^{3}\right)$, $D$ the diameter at breast height $(\mathrm{cm}), H$ tree height $(\mathrm{m})$, and $f$ an empirically derived form factor for beech trees (Bergel, 1973) with $f=0.4039+(0.0017335 \times H)+(1.1267 / H)-\left(118.188 / D^{3}\right)$ $+\left(4.2 \times 10^{6} \times D^{2}\right)$. Above-ground biomass was estimated from an empirical equation given by Wutzler et al. (2008) as AGB = $0.00523 \times D^{2.12} \times H^{0.655}$.

\section{Leaf-Related Measurements}

From each branch segment, all leaves were removed from the basipetal segment upwards to determine mean leaf size $\left(A_{\text {leaf }}\right.$,

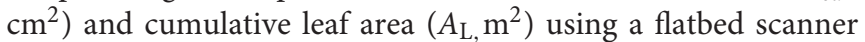
and the WinFOLIA software (Régent Instruments, Quebec, Canada). Per branch segment, 19 to 194 leaves were scanned, yielding 6008 leaves in total. Specific leaf area (SLA, $\mathrm{cm}^{2} \mathrm{~g}^{-1}$ ) was

TABLE 1 | Climatic data at the place of origin of the ten Fagus sylvatica provenances including elevation, mean annual temperature (MAT), mean annual precipitation (MAP), mean early growing season precipitation from April to June (MSP), Ellenberg's climate quotient (EQ), the global aridity index (GAI) and the forest aridity index (FAI).

\begin{tabular}{|c|c|c|c|c|c|c|c|c|c|}
\hline \multirow[t]{2}{*}{ Acronym } & \multirow[t]{2}{*}{ Country, location } & \multirow[t]{2}{*}{ Coordinates } & \multirow{2}{*}{$\frac{\text { Elevation }}{\mathrm{m}}$} & \multirow{2}{*}{$\begin{array}{c}\text { MAT } \\
{ }^{\circ} \mathbf{C}\end{array}$} & \multirow{2}{*}{$\begin{array}{c}\text { MAP } \\
\mathrm{mm} \mathrm{yr}^{-1}\end{array}$} & \multirow{2}{*}{$\begin{array}{c}\text { MSP } \\
\mathrm{mm} \mathrm{yr}^{-1}\end{array}$} & \multirow[t]{2}{*}{ EQ } & \multirow[t]{2}{*}{ GAI } & \multirow[t]{2}{*}{ FAl } \\
\hline & & & & & & & & & \\
\hline$B G$ & Bulgaria, Ribaritza, Lovetch & $42^{\circ} 55^{\prime} \mathrm{N}, 24^{\circ} 16^{\prime} \mathrm{E}$ & 900 & 15.3 & 945 & 214 & 32.12 & 0.67 & 6.09 \\
\hline $\mathrm{CZ}$ & Czech Republic, Kladanska, Lazne Kynzvart & $50^{\circ} 2^{\prime} \mathrm{N}, 12^{\circ} 37^{\prime} \mathrm{E}$ & 690 & 6.0 & 750 & 218 & 16.30 & 1.38 & 3.03 \\
\hline DE-BB & Germany, Gransee, Abt. 3082 a1 & $53^{\circ} \mathrm{O}^{\prime} \mathrm{N}, 13^{\circ} 10^{\prime} \mathrm{E}$ & 70 & 8.5 & 575 & 162 & 31.23 & 0.81 & 5.75 \\
\hline DE-SH & Germany, Schleswig Holstein, Lensahn & $54^{\circ} 12^{\prime} \mathrm{N}, 10^{\circ} 45^{\prime} \mathrm{E}$ & 80 & 8.3 & 700 & 162 & 22.41 & 1.16 & 4.63 \\
\hline ES & Spain, Anguiano La Rioja & $42^{\circ} 15^{\prime} \mathrm{N}, 2^{\circ} 45^{\prime} \mathrm{W}$ & 950 & 9.9 & 860 & 170 & 33.79 & 0.66 & 9.16 \\
\hline $\mathrm{RO}$ & Romania, Beliu-Arad /Groseni & $46^{\circ} 29^{\prime} \mathrm{N}, 22^{\circ} 9^{\prime} \mathrm{E}$ & 575 & 9.5 & 820 & 222 & 30.82 & 0.73 & 5.38 \\
\hline SE & Sweden, Ryssberget, Sölvesborg & $56^{\circ} 5^{\prime} \mathrm{N}, 14^{\circ} 36^{\prime} \mathrm{E}$ & 90 & 8.0 & 750 & 125 & 26.63 & 1.10 & 5.67 \\
\hline SK & Slovakia, Trencin & $48^{\circ} 53^{\prime} \mathrm{N}, 18^{\circ} \mathrm{O}^{\prime} \mathrm{E}$ & 200 & 9.0 & 670 & 211 & 27.99 & 0.79 & 4.59 \\
\hline SL & Slovenia, Rogaska Slatina & $46^{\circ} 18^{\prime} \mathrm{N}, 15^{\circ} 36^{\prime} \mathrm{E}$ & 420 & 9.0 & 1050 & 286 & 19.67 & 1.37 & 3.68 \\
\hline UA & Ukraine, Svaljava Polana & $48^{\circ} 38^{\prime} \mathrm{N}, 19^{\circ} 30^{\prime} \mathrm{E}$ & 1150 & 3.4 & 1080 & 354 & 11.53 & 1.76 & 2.00 \\
\hline
\end{tabular}

Mean annual climate data from 1950 to 2000 were obtained from the WorldClim database with 30 arc-seconds resolution (Hijmans et al., 2005). 
TABLE 2 | List of variables with acronyms and units employed.

\begin{tabular}{|c|c|c|}
\hline Variable & Unit & Definition \\
\hline DBH & $\mathrm{cm}$ & Diameter at breast height \\
\hline Height & $\mathrm{m}$ & Tree height \\
\hline AGB & $\mathrm{kg}$ & Aboveground biomass \\
\hline $\mathrm{BAl}$ & $\mathrm{cm}^{2} \mathrm{yr}^{-1}$ & Basal area increment \\
\hline $\mathrm{ABI}$ & $\mathrm{kg} \mathrm{yr} \mathrm{r}^{-1}$ & Aboveground biomass increment \\
\hline$P_{12}$ & $\mathrm{MPa}$ & $\begin{array}{l}\text { Xylem pressure at } 12 \% \text { loss of } \\
\text { hydraulic conductance }\end{array}$ \\
\hline$P_{50}$ & $\mathrm{MPa}$ & $\begin{array}{l}\text { Xylem pressure at } 50 \% \text { loss of } \\
\text { hydraulic conductance }\end{array}$ \\
\hline$P_{88}$ & $\mathrm{MPa}$ & $\begin{array}{l}\text { Xylem pressure at } 88 \% \text { loss of } \\
\text { hydraulic conductance }\end{array}$ \\
\hline$A_{\text {xylem }}$ & $\mathrm{mm}^{2}$ & Branch sapwood area \\
\hline$K_{S}^{e m p}$ & $\mathrm{~kg} \mathrm{~m}^{-1} \mathrm{MPa}^{-1} \mathrm{~s}^{-1}$ & Empirical specific conductivity \\
\hline$K_{S}^{\text {theo }}$ & $\mathrm{kg} \mathrm{m}^{-1} \mathrm{MPa}^{-1} \mathrm{~s}^{-1}$ & Theoretical specific conductivity \\
\hline$K_{\mathrm{L}}^{\mathrm{emp}}$ & & $\begin{array}{l}\text { Empirical leaf-specific } \\
\text { conductivity }\end{array}$ \\
\hline$K_{\mathrm{L}}^{\text {theo }}$ & $10^{-4} \mathrm{~kg} \mathrm{~m}^{-1} \mathrm{MPa}^{-1} \mathrm{~s}^{-1}$ & $\begin{array}{l}\text { Theoretical leaf-specific } \\
\text { conductivity }\end{array}$ \\
\hline BA & yr & Branch age \\
\hline$A_{\text {growth }}$ & $\mathrm{mm}^{2} \mathrm{yr}^{-1}$ & $\begin{array}{l}\text { Annual branch sapwood area } \\
\text { increment }\end{array}$ \\
\hline$A_{\text {lumen }}: A_{\text {xylem }}$ & $\%$ & Lumen to sapwood area ratio \\
\hline VD & $\mathrm{n} \mathrm{mm^{-2 }}$ & Vessel density \\
\hline$D$ & $\mu \mathrm{m}$ & Vessel diameter \\
\hline$D_{\mathrm{h}}$ & $\mu \mathrm{m}$ & $\begin{array}{l}\text { Hydraulically weighted vessel } \\
\text { diameter }\end{array}$ \\
\hline$A_{\text {leaf }}$ & $\mathrm{cm}^{2}$ & Mean leaf size \\
\hline SLA & $\mathrm{cm}^{2} \mathrm{~g}^{-1}$ & Specific leaf area \\
\hline$A_{S}: A_{L}$ & $10^{-4} \mathrm{~m}^{2} \mathrm{~m}^{-2}$ & $\begin{array}{l}\text { Sapwood to leaf area ratio } \\
\text { (Huber value) }\end{array}$ \\
\hline C:N & & Carbon to nitrogen ratio \\
\hline$\delta^{13} \mathrm{C}$ & $\%$ & Carbon isotope signature \\
\hline Camass & $\mathrm{g} \mathrm{kg}^{-1}$ & $\begin{array}{l}\text { Mass-specific foliar calcium } \\
\text { content }\end{array}$ \\
\hline$K_{\text {mass }}$ & $\mathrm{g} \mathrm{kg}^{-1}$ & $\begin{array}{l}\text { Mass-specific foliar potassium } \\
\text { content }\end{array}$ \\
\hline Mgmass & $\mathrm{g} \mathrm{kg}^{-1}$ & $\begin{array}{l}\text { Mass-specific foliar magnesium } \\
\text { content }\end{array}$ \\
\hline$N_{\text {mass }}$ & $\mathrm{g} \mathrm{kg}^{-1}$ & $\begin{array}{l}\text { Mass-specific foliar nitrogen } \\
\text { content }\end{array}$ \\
\hline$P_{\text {mass }}$ & $\mathrm{g} \mathrm{kg}^{-1}$ & $\begin{array}{l}\text { Mass-specific foliar phospor } \\
\text { content }\end{array}$ \\
\hline
\end{tabular}

calculated by dividing the total leaf area by the leaf dry weight $\left(70^{\circ} \mathrm{C}, 48 \mathrm{~h}\right)$. The Huber value, i.e., sapwood to leaf area ratio ( $A_{\mathrm{S}}: A_{\mathrm{L}}, 10^{-4} \mathrm{~m}^{2} \mathrm{~m}^{-2}$ ), was calculated by dividing maximal sapwood area by $A_{\mathrm{L}}$. Subsequently, leaf samples were ground and the leaf dry mass analyzed for foliar $C$ and $N$ concentrations as well as the carbon isotope signature $\left(\delta^{13} \mathrm{C}, \%\right.$ ) by using a Delta Plus Isotope mass ratio spectrometer (Finnigan MAT, Bremen, Germany), a Conflo III interface (Thermo Electron Corporation, Bremen, Germany) and a NA2500 elemental analyser (CEInstruments, Rodano, Milano, Italy) using standard $\delta$ notion: $\delta=\left(R_{\text {sample }} / R_{\text {standard }}-1\right) \times 1000(\%$ o $)$ at the Centre for Stable
Isotope Research and Analysis (KOSI), University of Göttingen. The foliar concentrations of $\mathrm{Ca}, \mathrm{K}, \mathrm{Mg}$, and $\mathrm{P}$ were measured by ICP analysis (Optima 5300 DV, PerkinElmer Inc., USA).

\section{Branch Xylem Anatomy, Theoretical Conductivity, and Growth Rate}

Measurements of anatomical parameters were carried out on 9-10 branch segments from the basipetal end of the samples used for the hydraulic measurements of each provenance, yielding 98 samples in total. Prior to cutting semi-thin (10$20 \mu \mathrm{m})$ transverse sections with a sliding microtome (G.S.L.1, Schenkung Dapples, Zürich, Switzerland), the ethanol-stored (70\%) segments were completely stained with a safranin solution ( 1 in $50 \%$ ethanol, Merck, Darmstadt, Germany) and subsequently embedded in Euparal medium. For digitalization, a stereo-microscope equipped with an automatic stage was used (SteREOV20, Carl Zeiss MicroImaging GmbH, Jena, Germany; Software: AxioVision v4.8.2, Carl Zeiss MicroImaging GmbH, Jena, Germany), enabling a time-efficient digitalization of the complete cross-section at $100 \mathrm{x}$ magnification. Image analysis was performed using the software Adobe Photoshop CS2 (Version 9.0, Adobe Systems Incorporated, USA) and ImageJ (v1.44p, http://rsb.info.nih.gov/ij) applying the particle analysis function. For all subsequent calculations, the complete xylem cross-section without pith and bark was analyzed, yielding 888,358 analyzed vessels in total. The following parameters were calculated: idealized vessel diameter $(D, \mu \mathrm{m})$ as obtained from major $(a)$ and minor $(b)$ vessel radii according to Lewis and Boose (1995) as $D=$ $\left(\left(32 \times(a \times b)^{3}\right) /\left(a^{2}+b^{2}\right)\right)^{1 / 4}$, vessel density $\left(\mathrm{VD}, \mathrm{n} \mathrm{mm}^{-2}\right)$ and cumulative vessel lumen area. The lumen to sapwood area ratio ( $\left.A_{\text {lumen }}: A_{\text {xylem }}, \%\right)$, was obtained by dividing cumulative vessel lumen area by the corresponding sapwood area. The diameter of individual vessels was used to calculate hydraulically-weighted vessel diameter $\left(D_{\mathrm{h}}, \mu \mathrm{m}\right)$ according to Sperry et al. (1994) as $D_{\mathrm{h}}$ $=\Sigma D^{5} / \Sigma D^{4}$. Theoretical specific conductivity $\left(K_{\mathrm{S}}^{\mathrm{theo}}, \mathrm{kg} \mathrm{m}^{-1}\right.$ $\left.\mathrm{MPa}^{-1} \mathrm{~s}^{-1}\right)$ was calculated according to the Hagen-Poiseuille equation as $K_{\mathrm{S}}^{\text {theo }}=\left(\left(\left(\pi \times \Sigma D^{4}\right) / 128 \eta\right) \times \rho\right) / A_{\text {xylem }}$, where $\eta$ is the viscosity of water (1.002 $\left.10^{-9} \mathrm{MPa} s\right), \rho$ the density of water $\left(998.2 \mathrm{~kg} \mathrm{~m}^{-3}\right)$, both at $20^{\circ} \mathrm{C}$, and $A_{\text {xylem }}\left(\mathrm{m}^{2}\right)$ the corresponding xylem area without pith and bark. Branch growth rate $\left(A_{\text {growth }}, \mathrm{mm}^{2} \mathrm{yr}^{-1}\right)$ was calculated by dividing $A_{\text {xylem }}$ by the number of growth rings (i.e., branch age, BA). In addition to $K_{\mathrm{S}}^{\text {theo }}$, theoretical leaf-specific conductivity was calculated by division by $A_{\mathrm{L}}$ as $K_{\mathrm{L}}^{\text {theo }}=\left(\left(\left(\pi \times \Sigma D^{4}\right) / 128 \eta\right) \times \rho\right) / A_{\mathrm{L}}$.

\section{Hydraulic Conductivity Measurement}

Hydraulic traits were measured in ten branch segments (mean diameter \pm SE: $6.83 \pm 0.06 \mathrm{~mm}$ ) per provenance using the Xyl'em apparatus (Bronkhorst, Montigny-les-Cormeilles, France). In the laboratory, all lateral branches were cut off and the scares sealed with quick-drying superglue (Loctite 431, Henkel, Düsseldorf, Germany) applicable to wet surfaces. Subsequently, the segments were shortened to a length of $290.5 \pm 0.8 \mathrm{~mm}$ (mean $\pm \mathrm{SE}$ ). For the determination of maximal hydraulic conductivity $\left(K_{\mathrm{h}}\right.$, $\left.\mathrm{kg} \mathrm{m} \mathrm{MPa} \mathrm{m}^{-1}\right)$ at $6 \mathrm{kPa}$, demineralized filtered $(0.22 \mu \mathrm{m})$ and degassed water $\left(10 \mathrm{mM} \mathrm{KCl}\right.$ and $\left.1 \mathrm{mM} \mathrm{CaCO}_{3}\right)$ was used, 
interrupted by three 10 -min flushes at $120 \mathrm{kPa}$ to assure removal off all potential emboli. The diameter of each segment was measured twice at the basipetal and distal end, and at four positions along the segment. The following regression coefficients were used to calculate sapwood area without pith and bark for a given beech branch segment diameter according to Schuldt et al. (2016): $A_{\text {xylem }}=-3.715+0.770 A_{\text {cross }}$. Subsequently, empirical specific conductivity $\left(K_{\mathrm{S}}^{\mathrm{emp}}, \mathrm{kg} \mathrm{m}^{-1} \mathrm{MPa}^{-1} \mathrm{~s}^{-1}\right)$ was calculated by dividing $K_{\mathrm{h}}$ by the maximal basipetal, and not average, sapwood area (Hajek et al., 2014; Hoeber et al., 2014; Schuldt et al., 2016). $K_{\mathrm{h}}$ was further used to calculate empirical leaf-specific conductivity $\left(K_{\mathrm{L}}^{\mathrm{emp}}, \mathrm{kg} \mathrm{m}^{-1} \mathrm{MPa}^{-1} \mathrm{~s}^{-1}\right)$ by division by $A_{\mathrm{L}}$.

\section{Xylem Resistance to Cavitation}

Vulnerability to xylem cavitation was determined on 8 to 10 branch samples (replicated trees) per provenance using the Cavitron technique (Cochard et al., 2005), yielding 94 samples in total. Segments with a standardized length of $27.5 \mathrm{~cm}$ were mounted in a custom-built honeycomb rotor chamber of the Cavitron, which uses a commercially available centrifuge as basis (Sorvall RC-5C, Thermo Fisher Scientific, Waltham, MA, USA), and spun at defined velocities recorded with the software CaviSoft (version 4.0.1.3, University of Bordeaux, France). Conductivity measurements started at $1.0 \mathrm{MPa}$ and were stepwise repeated at intervals of 0.2 to $0.3 \mathrm{MPa}$ until the percent loss of conductivity (PLC) reached at least $90 \%$. All vulnerability curves of the present study measured on $27.5 \mathrm{~cm}$ long segments were s-shaped, indicating that no open vessels were present. For each branch segment, a sigmoid function (Willigen and Pammenter, 1998) was fitted to describe the relationship between PLC and xylem pressure using the expression PLC $=100 /(1+\exp (s / 25 \times$ $\left.\left(P_{\mathrm{i}}-P_{50}\right)\right)$ ), where $P_{50}(\mathrm{MPa})$ is the xylem tension causing $50 \%$ loss of hydraulic conductivity and $s\left(\% \mathrm{MPa}^{-1}\right)$ is the slope of the curve at the inflexion point. The xylem pressures causing $12 \%$ $\left(P_{12}\right)$ and $88 \%\left(P_{88}\right)$ loss of conductivity were calculated as well.

\section{Statistical Analysis}

In order to assess the significance of differentiation between provenances for all functional traits, we used linear mixed effect models (LME) starting with a random effect model without any fixed effect but with "provenance" and "block" added as a random effects using the "lme" function of the R package "nlme" according to the following model [1]: $Y_{i j k}=\mu+P_{i}+b_{j}+$ $\varepsilon_{i j k}$, where $Y_{i j k}$ is the observation of tree individual $k$ for one of the analyzed characters from provenance $i$ and block $j, \mu$ is the overall mean, and $P_{\mathrm{i}}$ the error term for provenance, $b_{\mathrm{j}}$ for block and $\varepsilon_{\mathrm{ijk}}$ for the residual variation. During the analysis, normal distribution of the residuals and homogeneity of variance were assessed visually using residual diagnostics and quantile-quantile plots; some data $\left(K_{\mathrm{L}}^{\mathrm{emp}}, K_{\mathrm{L}}^{\text {theo }}, A_{\mathrm{S}}: A_{\mathrm{L}}\right)$ had to be log-transformed in order to achieve normal distribution. In order to test whether the variance component accounting for genetic differentiation is significantly different from zero, a likelihood ratio test (LRT) was performed against a reduced model without a random effect for provenance using the restricted maximum likelihood (REML) method. As under those conditions the LRT is performed on the boundary of the parameter space, the resulting $P$-values had to be corrected by multiplying them by 0.5 (Verbeke and Molenberghs, 2009).

To quantify the influence of climate at the place of origin, FAI was added to the LME as fixed variable according to the following model [2]: $Y_{i j k}=\alpha+\beta \mathrm{FAI}_{i}+P_{i}+b_{j}+\varepsilon_{i j k}$, where $\alpha$ is the intercept and $\beta$ the slope of the linear model with $\mathrm{FAI}_{i}$, which all three together determine $\mu$ of model [1]. A significant influence of climate at provenance origin was determined by a LRT using the maximum likelihood (ML) method.

We further calculated coefficients of variation for withinprovenance variation $\left(\mathrm{CV}_{\text {intra }}\right)$ and between-provenance variation $\left(\mathrm{CV}_{\text {inter }}\right)$ for each trait in order to allocate total measured trait variation to a genetic component $\left(\mathrm{CV}_{\text {inter }}\right)$ and a predominantly phenotypic component $\left(\mathrm{CV}_{\text {intra }}\right)$; the between-provenance variability $\left(\mathrm{CV}_{\text {inter }}\right)$ was calculated from the between-provenance standard deviation (SD) and the overall mean value. Additionally, the ratio of provenance variance component to total variance was calculated using the $\mathrm{R}$ package "varComp" according to a variance component analyses with the program "lme" to calculate the proportion of total variance $\left(\sigma_{\text {total }}^{2}\right)$ explained by the variability between provenances $\left(\sigma_{\text {inter }}^{2}\right)$, replicated randomly distributed "blocks" $\left(\sigma_{\text {block }}^{2}\right)$ and residual variance within provenances $\left(\sigma_{\text {intra }}^{2}\right)$. Inter-population variance component $\left(\mathrm{VC}_{\text {inter }}\right)$ was calculated according to $\mathrm{VC}_{\text {inter }}=$ $\left(\sigma_{\text {inter }}^{2} /\left(\sigma_{\text {inter }}^{2}+\sigma_{\text {block }}^{2}+\sigma_{\text {intra }}^{2}\right)\right) \times 100$, variance component between replicated plots as $\mathrm{VC}_{\text {block }}=\left(\sigma_{\text {block }}^{2} /\left(\sigma_{\text {inter }}^{2}+\sigma_{\text {block }}^{2}\right.\right.$ $\left.\left.+\sigma_{\text {intra }}^{2}\right)\right) \times 100$, and intra-population variance component $\left(\mathrm{VC}_{\text {intra }}\right)$ as $\mathrm{VC}_{\text {intra }}=\left(\sigma_{\text {intra }}^{2} /\left(\sigma_{\text {intra }}^{2}+\sigma_{\text {block }}^{2}+\sigma_{\text {inter }}^{2}\right)\right) \times 100$, all in percentage.

Pearson correlation analysis was used to test for interrelationships between different branch traits of the trees and for detecting relationships between traits based on data pooled across all provenances. Applying correlations to raw measurements for such exploratory analysis may mix several sources of variation and result in inflated degrees of freedom and potentially overestimation of significance. Statistical analyses were performed with the software $\mathrm{R}$ (version 3.1.3, $\mathrm{R}$ Development Core Team, 2011), and all linear and non-linear regression analyses were carried out with the software Xact 8.03 (SciLab, Hamburg, Germany).

\section{RESULTS}

\section{Genetic Differentiation between Provenances}

The estimate of aboveground growth potential as inferred from the basal area increment (BAI) from January 2013 to August 2014 and aboveground biomass increment (ABI) for the entire length of the experiment from August 1995 to August 2014 revealed large significant differences between the ten selected beech provenances (Table 3). The provenances with highest ABI from Slovakia and Ukraine (SK: 3.6; UA $4.0 \mathrm{~kg} \mathrm{yr}^{-1}, P<$ 0.001; Table S1) showed four times higher growth rates than the provenances with lowest growth rates from Slovenia and Sweden (SL: 1.02 and SE: $1.69 \mathrm{~kg} \mathrm{yr}^{-1}$; Table S1). Both provenances 
TABLE 3 | Results of a random effects model on the genetic differentiation between provenances and the coefficient of variation for all traits measured for the variability between provenances $\left(\mathbf{C V}_{\text {inter }}\right)$ and within provenances $\left(\mathbf{C V}_{\text {intra }}\right)$.

\begin{tabular}{|c|c|c|c|c|c|c|c|c|}
\hline \multicolumn{9}{|c|}{ GENETIC DIFFERENTATION BETWEEN PROVENANCES } \\
\hline Variable & $\mathbf{C V}_{\text {inter }}$ & $\mathbf{C V}_{\text {intra }}$ & VC $_{\text {inter }}$ & $\mathrm{vC}_{\text {block }}$ & vC $_{\text {intra }}$ & $\Delta_{\mathbf{i}}$ & LR & $P$ \\
\hline \multicolumn{9}{|c|}{ STAND CHARACTERISTICS } \\
\hline $\mathrm{DBH}$ & 15.46 & 11.00 & 64.23 & 0.96 & 34.81 & 24.19 & 26.19 & $<0.001$ \\
\hline Height & 11.95 & 10.52 & 49.82 & 11.48 & 38.70 & 11.40 & 13.40 & $<0.001$ \\
\hline AGB & 36.98 & 25.44 & 66.73 & 0.00 & 33.27 & 32.88 & 34.88 & $<0.001$ \\
\hline \multicolumn{9}{|c|}{ GROWTH-RELATED TRAITS } \\
\hline $\mathrm{BAl}$ & 54.20 & 56.81 & 40.51 & 0.36 & 59.13 & 10.42 & 12.42 & $<0.001$ \\
\hline $\mathrm{ABI}$ & 37.00 & 25.44 & 66.79 & 0.00 & 33.21 & 32.89 & 34.89 & $<0.001$ \\
\hline \multicolumn{9}{|c|}{ HYDRAULIC PROPERTIES } \\
\hline$P_{12}$ & 7.88 & 14.51 & 8.38 & 25.20 & 66.43 & 1.41 & 0.59 & 0.22 \\
\hline$P_{50}$ & 4.69 & 8.12 & 9.86 & 23.80 & 66.34 & 1.20 & 0.80 & 0.19 \\
\hline$P_{88}$ & 4.87 & 7.20 & 8.38 & 25.20 & 66.43 & 2.18 & 4.18 & 0.02 \\
\hline$K_{\mathrm{S}}^{\mathrm{emp}}$ & 9.65 & 27.59 & 0.00 & 8.78 & 91.22 & 2.00 & 0.00 & 0.50 \\
\hline$K_{S}^{\text {theo }}$ & 15.69 & 35.52 & 6.93 & 0.00 & 93.07 & 0.57 & 1.43 & 0.12 \\
\hline$K_{\mathrm{L}}^{\mathrm{emp}}$ & 17.37 & 50.38 & 0.00 & 9.35 & 90.65 & 2.00 & 0.00 & 0.50 \\
\hline$K_{L}^{\text {theo }}$ & 21.45 & 65.24 & 0.00 & 4.99 & 95.01 & 2.00 & 0.00 & 0.50 \\
\hline \multicolumn{9}{|c|}{ WOOD ANATOMY } \\
\hline $\mathrm{BA}$ & 7.63 & 19.81 & 0.99 & 0.00 & 99.01 & 1.96 & 0.04 & 0.42 \\
\hline$A_{\text {growth }}$ & 4.65 & 23.86 & 0.00 & 0.00 & 100.00 & 2.00 & 0.00 & 0.50 \\
\hline$A_{\text {lumen }}: A_{\text {xylem }}$ & 9.45 & 19.93 & 9.57 & 0.00 & 90.43 & -0.56 & 2.56 & 0.05 \\
\hline VD & 6.72 & 12.58 & 14.02 & 0.00 & 85.98 & 2.67 & 4.67 & 0.02 \\
\hline$D$ & 4.09 & 8.32 & 10.10 & 0.00 & 89.90 & -0.51 & 2.51 & 0.06 \\
\hline$D_{\mathrm{h}}$ & 3.75 & 9.14 & 5.31 & 0.00 & 94.69 & 1.20 & 0.80 & 0.19 \\
\hline \multicolumn{9}{|c|}{ LEAF MORPHOLOGY } \\
\hline$A_{\text {leaf }}$ & 9.07 & 18.08 & 12.09 & 0.00 & 87.91 & 0.77 & 2.77 & 0.05 \\
\hline SLA & 7.28 & 23.88 & 0.00 & 3.86 & 96.14 & 2.00 & 0.00 & 0.50 \\
\hline$A_{S}: A_{L}$ & 16.03 & 39.55 & 2.75 & 1.06 & 96.19 & 1.81 & 0.19 & 0.33 \\
\hline \multicolumn{9}{|c|}{ LEAF CHEMISTRY } \\
\hline C:N & 3.02 & 6.56 & 9.77 & 0.00 & 90.23 & 0.37 & 2.37 & 0.06 \\
\hline$\delta^{13} \mathrm{C}$ & 1.16 & 2.73 & 6.48 & 0.00 & 93.52 & 0.88 & 1.12 & 0.14 \\
\hline Camass & 5.67 & 21.72 & 0.00 & 0.00 & 100.00 & 2.00 & 0.00 & 0.50 \\
\hline $\mathrm{K}_{\text {mass }}$ & 11.43 & 23.55 & 9.85 & 0.00 & 90.15 & 0.20 & 2.20 & 0.07 \\
\hline Mgmass & 9.12 & 24.36 & 1.66 & 0.00 & 98.34 & 1.90 & 0.10 & 0.38 \\
\hline$P_{\text {mass }}$ & 3.81 & 13.12 & 0.00 & 0.00 & 100.00 & 2.00 & 0.00 & 0.50 \\
\hline
\end{tabular}

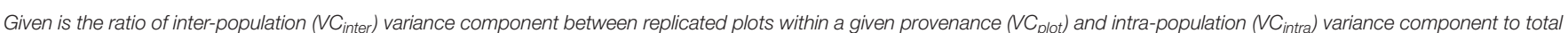

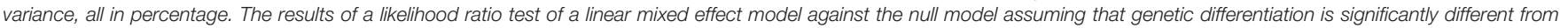

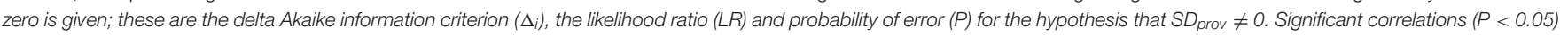
are printed in bold, marginally significant correlations $(P<0.10)$ in italic bold letters.

had the highest radial growth rates (SK: 33.36 and UA: 23.20 $\mathrm{cm}^{2} \mathrm{yr}^{-1}$ ) and grew more than seven-fold compared to the two provenances with lowest basal area increment (ES: 4.34 and SL: $5.68 \mathrm{~cm}^{2} \mathrm{yr}^{-1}$; Table S1). The other six provenances reached intermediate growth rates $\left(13.05-22.55 \mathrm{~cm}^{2} \mathrm{yr}^{-1}\right)$. ABI and BAI scaled highly positive with tree size $\left(\mathrm{DBH}, r^{2}=0.98, P<0.001\right.$ and $r^{2}=0.73, P<0.001$; height, $r^{2}=0.66, P<0.01$ and $r^{2}=$ $0.31, P<0.001$; Table 5).

Significant genetic differentiations between provenances were found in three out of 22 ecophysiological traits only, namely the xylem pressure inducing $88 \%$ loss of hydraulic conductance $\left(P_{88}\right)$, vessel density $(\mathrm{VD})$ and mean leaf size $\left(A_{\text {leaf }}\right.$; Table 3$)$.
The $P_{88}$ values ranged from $-3.60 \mathrm{MPa}$ for the most vulnerable provenance from Germany (DE-BB) to $-4.21 \mathrm{MPa}$ for the most resistant provenance from Slovenia (SL), i.e., by $15 \%$ (Table S1). The differences in embolism resistance between provenances were, however, not mirrored in xylem anatomical adjustments. VD was significantly higher in the branch xylem of the mostproductive provenances from Slovakia (SK) and the Ukraine (UA) while the largest leaves were found for the provenance adapted to the local climate of Schleswig Holstein (DE-SH; Table S1). Other provenances from Sweden (SE) and Czech Republic (CZ) produced on average 30\% smaller leaves, which was not mirrored in adjustments of specific leaf area (SLA) or the Huber 

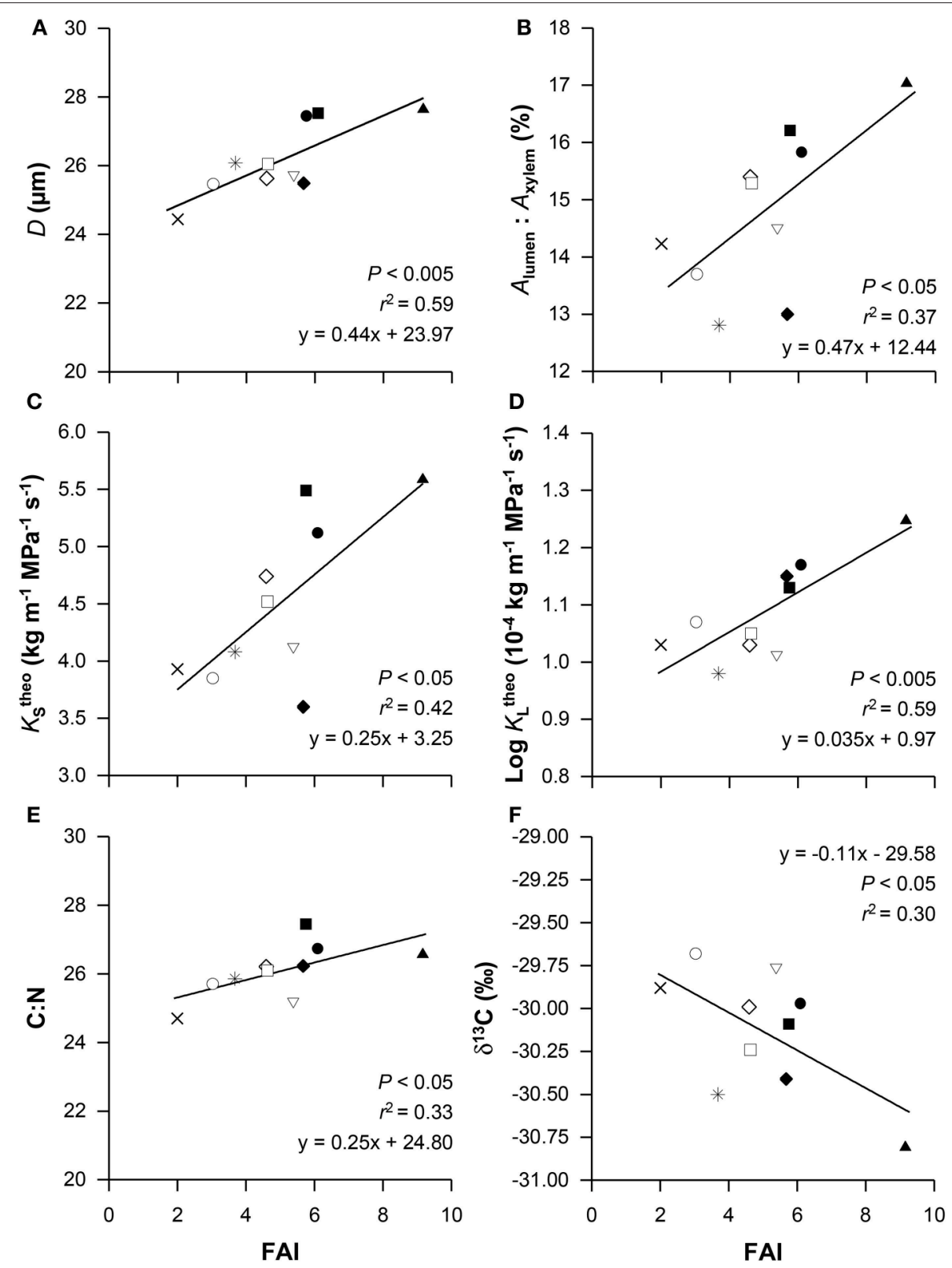

FIGURE 1 | Relationship between the forest aridity index (FAI) at the place of origin and vessel diameter ( $D$, A), lumen to sapwood area ratio $\left(A_{\text {lumen }}\right.$ : $\left.A_{\text {xylem }}, B\right)$, theoretical specific conductivity $\left(K_{S}^{\text {theo }}, C\right)$, theoretical leaf-specific conductivity $\left(K_{L}^{\text {theo }}, D\right)$, the carbon to nitrogen ratio $(C: N$, E) and the carbon isotope signature $\left({ }^{13} \mathbf{C}, \mathbf{F}\right)$. Given values are means per provenance. Each symbol represents one provenance, for provenance abbreviations see Table 1

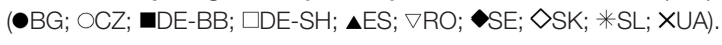

value $\left(A_{S}: A_{L}\right)$. In general, the leaf chemistry was uniform across the provenances.

Significant genetic differentiation between provenances (Table 3) was mirrored in high values of inter-population variance component $\left(\mathrm{VC}_{\text {inter }}\right)$ for these three ecophysiological traits $\left(P_{88}, \mathrm{VD}, A_{\text {leaf }}\right)$ ranging from 8.38 to $14.02 \%$ (Table 3 ). Interestingly, all three measures of embolism resistance showed a higher variance between blocks ( $\mathrm{VC}_{\text {block }}: \sim 25 \%$ ) than between populations $\left(\mathrm{VC}_{\text {inter }}: \sim 10 \%\right)$. The remaining measured hydraulic traits, empirical specific conductivity $\left(K_{S}^{\mathrm{emp}}\right)$ and empirical leaf-specific conductivity $\left(K_{\mathrm{L}}^{\mathrm{emp}}\right)$, likewise differed by $\sim 10 \%$ between blocks but showed no variance between populations. Contrary to these hydraulic traits, all wood anatomical and calculated theoretical specific conductivity $\left(K_{S}^{\text {theo }}\right)$ revealed no variance between blocks. For all traits measured excluding the growth-related variables, variability within provenances $\left(\mathrm{CV}_{\text {intra }}\right)$ was about two times higher than variability between provenances $\left(\mathrm{CV}_{\text {inter }}\right.$; Table 3$)$. 


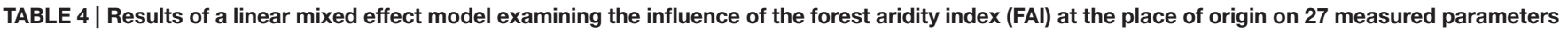
19 years after planting of the provenance trial in Northern Germany.

\begin{tabular}{|c|c|c|c|c|c|c|c|c|c|}
\hline \multicolumn{10}{|c|}{ RELATEDNESS TO CLIMATE AT PROVENANCE ORIGIN } \\
\hline Variable & $n$ & $\alpha \pm \mathrm{SE}$ & $\beta \pm \mathrm{SE}$ & $S D_{\text {prov }}$ & $S D_{\text {block }}$ & $S D_{\text {resid }}$ & $\Delta_{\mathbf{i}}$ & LR & $\boldsymbol{P}$ \\
\hline \multicolumn{10}{|c|}{ STAND CHARACTERISTICS } \\
\hline $\mathrm{DBH}$ & 100 & $12.67 \pm 1.71$ & $-0.18 \pm 0.32$ & 1.84 & 0.21 & 1.30 & 1.59 & 0.41 & 0.52 \\
\hline Height & 100 & $10.13 \pm 1.16$ & $0.001 \pm 0.22$ & 1.20 & 0.54 & 0.99 & 2.00 & 0.00 & 0.97 \\
\hline AGB & 100 & $56.77 \pm 16.19$ & $-2.01 \pm 3.04$ & 17.45 & 0.00 & 11.91 & 1.47 & 0.53 & 0.47 \\
\hline \multicolumn{10}{|c|}{ GROWTH-RELATED TRAITS } \\
\hline $\mathrm{BAl}$ & 100 & $25.19 \pm 7.78$ & $-1.81 \pm 1.46$ & 7.95 & 0.82 & 9.92 & 0.25 & 1.75 & 0.19 \\
\hline $\mathrm{ABI}$ & 100 & $2.99 \pm 0.85$ & $-0.11 \pm 0.16$ & 0.92 & 0.00 & 0.63 & 1.47 & 0.53 & 0.47 \\
\hline \multicolumn{10}{|c|}{ HYDRAULIC PROPERTIES } \\
\hline$P_{12}$ & 93 & $-2.15 \pm 0.16$ & $0.01 \pm 0.03$ & 0.11 & 0.17 & 0.28 & 1.93 & 0.07 & 0.80 \\
\hline$P_{50}$ & 93 & $-3.13 \pm 0.12$ & $0.03 \pm 0.02$ & 0.08 & 0.14 & 0.22 & 0.43 & 1.57 & 0.21 \\
\hline$P_{88}$ & 93 & $-4.06 \pm 0.16$ & $0.04 \pm 0.03$ & 0.14 & 0.07 & 0.29 & 0.20 & 1.80 & 0.18 \\
\hline$K_{\mathrm{S}}^{\mathrm{emp}}$ & 96 & $3.70 \pm 0.37$ & $0.004 \pm 0.07$ & 0.00 & 0.35 & 1.03 & 1.99 & 0.01 & 0.91 \\
\hline$K_{S}^{\text {theo }}$ & 98 & $3.24 \pm 0.51$ & $0.25 \pm 0.09$ & 0.10 & 0.00 & 1.69 & 4.26 & 6.26 & 0.01 \\
\hline$K_{\mathrm{L}}^{\mathrm{emp}}{ }^{*}$ & 95 & $2.04 \pm 0.18$ & $0.03 \pm 0.04$ & 0.00 & 0.16 & 0.51 & 0.98 & 1.02 & 0.31 \\
\hline$K_{\mathrm{L}}^{\text {theo* }}$ & 95 & $2.09 \pm 0.18$ & $0.08 \pm 0.03$ & 0.00 & 0.00 & 0.61 & 4.03 & 6.03 & 0.01 \\
\hline \multicolumn{10}{|c|}{ WOOD ANATOMY } \\
\hline BA & 100 & $2.56 \pm 0.15$ & $-0.06 \pm 0.03$ & 0.00 & 0.00 & 0.51 & 3.17 & 5.17 & 0.02 \\
\hline$A_{\text {growth }}$ & 98 & $16.42 \pm 1.20$ & $0.19 \pm 0.22$ & 0.00 & 0.00 & 4.07 & 1.29 & 0.71 & 0.40 \\
\hline$A_{\text {lumen }}: A_{\text {xylem }}$ & 98 & $12.40 \pm 1.03$ & $0.48 \pm 0.19$ & 0.53 & 0.00 & 3.09 & 3.72 & 5.72 & 0.02 \\
\hline VD & 98 & $245.92 \pm 15.88$ & $-0.27 \pm 2.97$ & 14.11 & 0.00 & 31.90 & 1.99 & 0.01 & 0.92 \\
\hline$D$ & 98 & $23.99 \pm 0.67$ & $0.43 \pm 0.13$ & 0.00 & 0.00 & 2.28 & 7.45 & 9.45 & 0.002 \\
\hline$D_{\mathrm{h}}$ & 98 & $32.05 \pm 1.07$ & $0.33 \pm 0.20$ & 0.58 & 0.00 & 3.18 & 0.84 & 2.84 & 0.09 \\
\hline \multicolumn{10}{|c|}{ LEAF MORPHOLOGY } \\
\hline$A_{\text {leaf }}$ & 100 & $23.98 \pm 2.08$ & $-0.20 \pm 0.39$ & 1.82 & 0.00 & 4.44 & 2.00 & 0.00 & 0.95 \\
\hline SLA & 99 & $158.61 \pm 12.16$ & $-0.72 \pm 2.28$ & 0.00 & 8.79 & 39.16 & 1.89 & 0.11 & 0.74 \\
\hline$A_{S}: A_{L}^{*}$ & 100 & $0.74 \pm 0.12$ & $0.04 \pm 0.02$ & 0.03 & 0.03 & 0.42 & 1.04 & 3.04 & 0.08 \\
\hline \multicolumn{10}{|c|}{ LEAF CHEMISTRY } \\
\hline $\mathrm{C}: \mathrm{N}$ & 100 & $24.80 \pm 0.59$ & $0.25 \pm 0.11$ & 0.35 & 0.00 & 1.73 & 3.12 & 5.12 & 0.02 \\
\hline$\delta^{13} \mathrm{C}$ & 100 & $-29.59 \pm 0.27$ & $-0.11 \pm 0.05$ & 0.12 & 0.00 & 0.86 & 2.63 & 4.63 & 0.03 \\
\hline Camass & 100 & $8.52 \pm 0.53$ & $-0.06 \pm 0.10$ & 0.00 & 0.15 & 1.79 & 1.66 & 0.34 & 0.56 \\
\hline $\mathrm{K}_{\text {mass }}$ & 100 & $4.54 \pm 0.51$ & $0.13 \pm 0.10$ & 0.39 & 0.00 & 1.30 & 0.09 & 2.09 & 0.15 \\
\hline Mgmass & 100 & $1.62 \pm 0.12$ & $-0.03 \pm 0.02$ & 0.03 & 0.00 & 0.39 & 0.03 & 2.03 & 0.15 \\
\hline Pmass & 100 & $1.21 \pm 0.05$ & $0.001 \pm 0.01$ & 0.00 & 0.00 & 0.18 & 1.98 & 0.02 & 0.89 \\
\hline
\end{tabular}

Given are intercept $\alpha$ and slope $\beta$ indicating the direction of the relationship for FAl with their corresponding standard errors (SE), standard deviation between provenances (SD prov) as

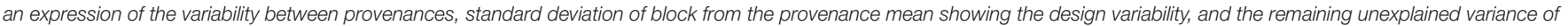

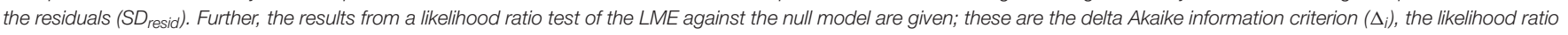

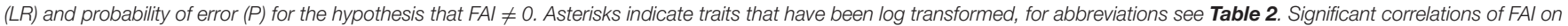
any given trait $(P<0.05)$ are printed in bold, marginally significant correlations $(P<0.10)$ in italic bold letters.

\section{Trait-Relatedness to Climate at Origin}

We observed several significant linear relationships between functional traits and the forest aridity index (FAI) as a measure of the climatic conditions at the place of provenance origin (Figure 1). These simple linear regression analyses were supported by linear mixed effect models confirming that FAI had a significant influence on seven of the 27 measured functional traits (Table 4). With increasing FAI, vessel diameter $(D)$, lumen to sapwood area ratio $\left(A_{\text {lumen }}: A_{\text {xylem }}\right)$, theoretical specific conductivity $\left(K_{\mathrm{S}}^{\text {theo }}\right)$, theoretical leaf-specific conductivity $\left(K_{\mathrm{L}}^{\text {theo }}\right)$ and the C:N ratio significantly increased while the carbon isotope signature $\left(\delta^{13} \mathrm{C}\right)$ declined (Figures 1A-F; Table 4).
Surprisingly, the three traits showing genetic differentiation between provenances $\left(P_{88}, \mathrm{VD}\right.$ and $\left.A_{\text {leaf }}\right)$ were not significantly affected by FAI. However, our results show that provenances originating from dry habitats with high FAI values (e.g., BG, ES, DE-BB) form particularly wide vessels and have high lumen to sapwood area ratios (Figures 1A,B) resulting in a high $K_{S}^{\text {theo }}$ (Figure 1C) and $K_{\mathrm{L}}^{\text {theo }}$ (Figure 1D) compared to the other provenances when grown at this humid site with high precipitation rates received during the entire growing season. The $\mathrm{C}: \mathrm{N}$ ratio was also significantly positively related to $\mathrm{FAI}$, while a strong significant negative relationship between FAI and $\delta^{13} \mathrm{C}$ was observed (Figure 1F). 

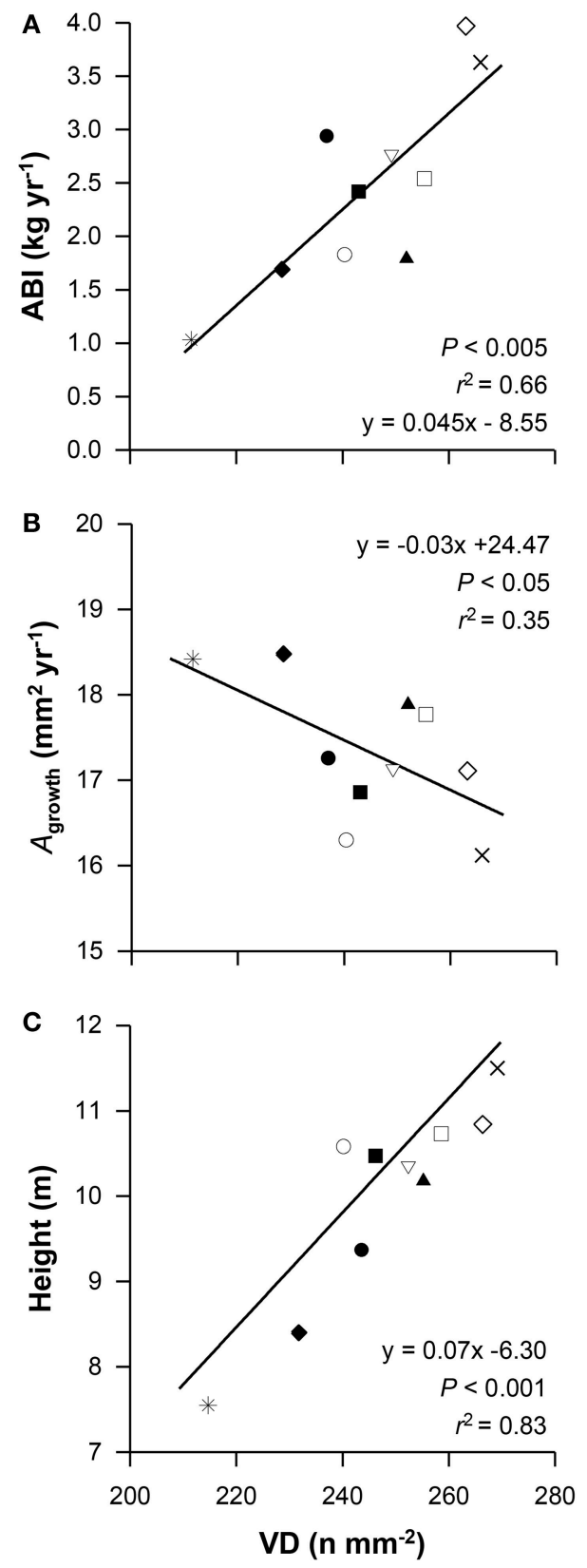

FIGURE 2 | Relationship between vessel density (VD) and aboveground biomass increment ( $\mathrm{ABI}, \mathrm{A})$, annual branch sapwood area increment $\left(\boldsymbol{A}_{\text {growth }}, \mathbf{B}\right)$, and tree height (C). Given values are means per provenance, for symbol definition see Figure 1.

\section{Determinants of Aboveground Growth Performance}

Among the xylem anatomical traits, only VD was positively related to aboveground biomass increment (ABI; $r^{2}=0.66, P<$ 0.005 ; Figure $2 \mathrm{~A}$ ) and negatively to branch growth rate $\left(A_{\text {growth }}\right.$; $r^{2}=0.35, P<0.05$; Figure 2B), which is a simplified measure of the annually produced branch sapwood, at the provenance level $(n=10)$. At the tree level $(n=100)$, only the negative relation between VD and $A_{\text {growth }}$ could be confirmed $\left(r^{2}=0.26, P<\right.$ 0.001; Table 5). Moreover, VD strongly increased with increasing tree height $\left(r^{2}=0.83, P<0.001\right.$; Figure $\left.2 \mathrm{C}\right)$. The remaining branch wood anatomical and hydraulic properties, however, varied independently from aboveground growth performance, and no correlations were found between ABI, embolism resistance and hydraulic efficiency, respectively (Table 5). However, a weak though significant negative relation was found for basal area increment (BAI) and $P_{50}$ at the tree level $\left(r^{2}=\right.$ 0.08, $P<0.01$; Table 5). Although we only observed weak or no relations between $\mathrm{ABI}$ and the wood anatomical and hydraulic traits, several of them were related to $A_{\text {growth }}$ (Table 5). Hence, the expected trade-off between hydraulic efficiency and growth could be confirmed at branch level, but not at the tree level.

\section{Inter-Relationships between Functional Traits}

We found that hydraulic efficiency in beech depends on the xylem properties. The vessel lumen to sapwood area ratio $\left(A_{\text {lumen }}\right.$ : $\left.A_{\text {xylem }}\right)$, annual branch growth rate $\left(A_{\text {growth }}\right)$, vessel diameter $(D)$ and hydraulically-weighed vessel diameter $\left(D_{\mathrm{h}}\right)$ were closely positively related to empirical specific conductivity $\left(K_{\mathrm{S}}^{\mathrm{emp}}\right)$ and empirical leaf-specific conductivity $\left(K_{\mathrm{L}}^{\mathrm{emp}}\right)$. In contrast, correlations between vessel density (VD) and the hydraulic traits $K_{\mathrm{S}}^{\mathrm{emp}}$ or $K_{\mathrm{S}}^{\text {theo }}$ were not found (Table 5). Furthermore, none of the wood anatomical traits were related to embolism resistance and the expected trade-off between hydraulic conductivity and embolism resistance was absent. In addition, we found significant links between functional leaf traits such as specific leaf area (SLA) and empirical as well as theoretical leaf-specific conductivity $\left(K_{\mathrm{L}}^{\mathrm{emp}}, K_{\mathrm{L}}^{\text {theo }}\right)$. The carbon isotope signature $\left(\delta^{13} \mathrm{C}\right)$ was positively correlated with $\mathrm{ABI}$ (fast growth was associated with a frequent stomatal closure) but negatively with the $P_{50}$ value (Figures $\mathbf{3 A}, \mathbf{B}$ ). The provenances with the highest growth rates (UA, SK, and BG) exhibited highest carbon isotope signature $\left(r^{2}=0.29, P<0.05\right.$; Figure 3A). The foliar C:N ratio was positively related to vessel diameter $(D)$ and the theoretical specific conductivity $\left(K_{S}^{\text {theo }}\right.$; Figures $\left.4 A, B\right)$, indicating that higher growth rates (associated with a high $\mathrm{C}: \mathrm{N}$ ratio) were indirectly related to xylem hydraulic properties of the branch wood.

\section{DISCUSSION}

\section{Genetic Differentiation}

Only recently, a growing number of studies have investigated the intraspecific genetic differentiation in ecophysiological traits between populations (e.g., Bresson et al., 2011; Lamy et al., 2011; Eilmann et al., 2014; Aranda et al., 2015; Schreiber et al., 2015). Despite this positive trend, common-garden studies that have reported anatomical or hydraulic traits are still scarce (Anderegg and Meinzer, 2015). Our study on ten European beech provenances native to different localities in Europe revealed little intraspecific variation of the ecophysiological traits covered. In agreement with former common-garden experiments we observed no significant genetic differences between populations for the xylem pressure causing $50 \%$ loss of 


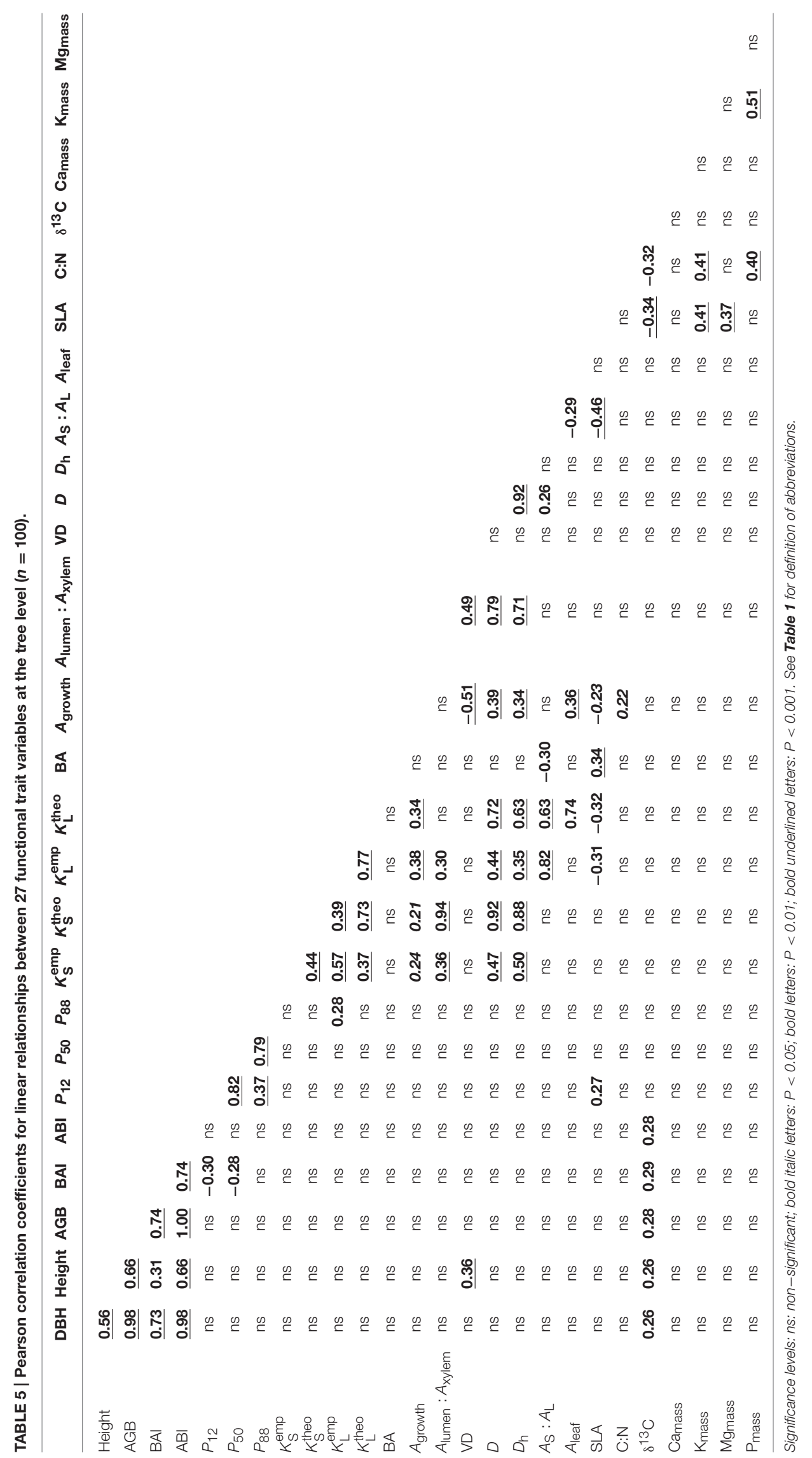


conductivity. The same pattern has been described for conifers (Sáenz-Romero et al., 2013; Lamy et al., 2014) as well as for beech (Wortemann et al., 2011, but see Aranda et al., 2015).
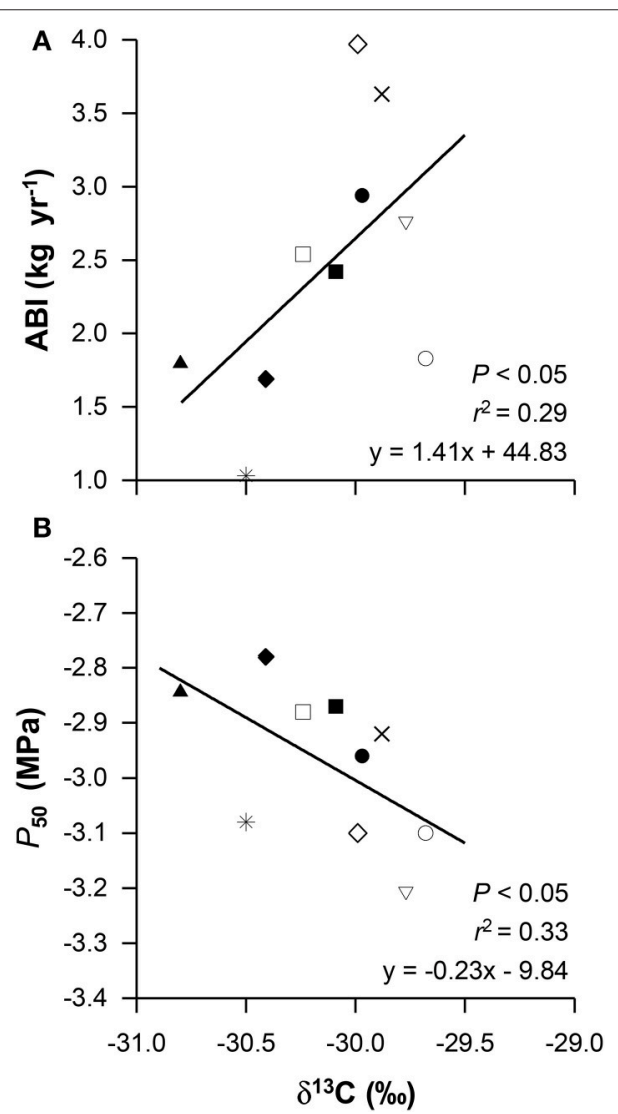

FIGURE 3 | Aboveground biomass increment (ABI, A) and the xylem pressure causing $\mathbf{5 0 \%}$ loss of hydraulic conductivity $\left(P_{50}, B\right)$ in relation to the carbon isotope signature. Given values are means per provenance, for symbol definition see Figure 1.
Contrary to these studies, however, we observed significant genetic differentiation for the xylem pressure inducing $88 \%$ loss of hydraulic conductance $\left(P_{88}\right)$, which corresponds to the threshold for catastrophic hydraulic failure leading to irreversible drought-induced dysfunction in angiosperms (Urli et al., 2013; Li et al., 2015). In our study, genetic differentiation was further found for the xylem anatomical trait vessel density and the foliar trait mean leaf size. Our first hypothesis postulating that wood hydraulic properties are under genetic control due to local adaptation is further supported by the observation that most wood anatomical and derived hydraulic traits as well as some foliar traits were closely related to the climate at provenance origin. These results may indicate that wood anatomical and hydraulic traits of beech reflect genetic differentiation between provenances although no significant intraspecific differences became evident. This is in line with the observation that several wood properties related to vessel size are predominantly under genetic predisposition (Eilmann et al., 2014).

However, the high intra-population variability in all ecophysiological traits covered, which was on average two to three times higher than inter-population variability, is also a strong evidence for the high genetic diversity within provenances. For example, Aranda et al. (2015) stated that beech exhibits a high degree of intra-population genetic variability for embolism resistance. This indicates that European beech might have a high potential capacity to adapt to climate change. In agreement hereon, both hydraulic efficiency and embolism resistance were unrelated to climatic aridity at the place of provenance origin and showed the highest variance within a given provenance $(\sim 65 \%)$, followed by the second highest variance between replicated blocks $(\sim 25 \%)$ due to microenvironmental effects including within-canopy variability, and only a comparatively low variance between populations $(\sim 10 \%)$. This likewise confirms that beech exhibits a high degree of intra-population genetic variability for embolism resistance. Surprisingly, provenances originating from drought prone habitats (e.g., ES, BG, and DE-BB) grown at our site do not
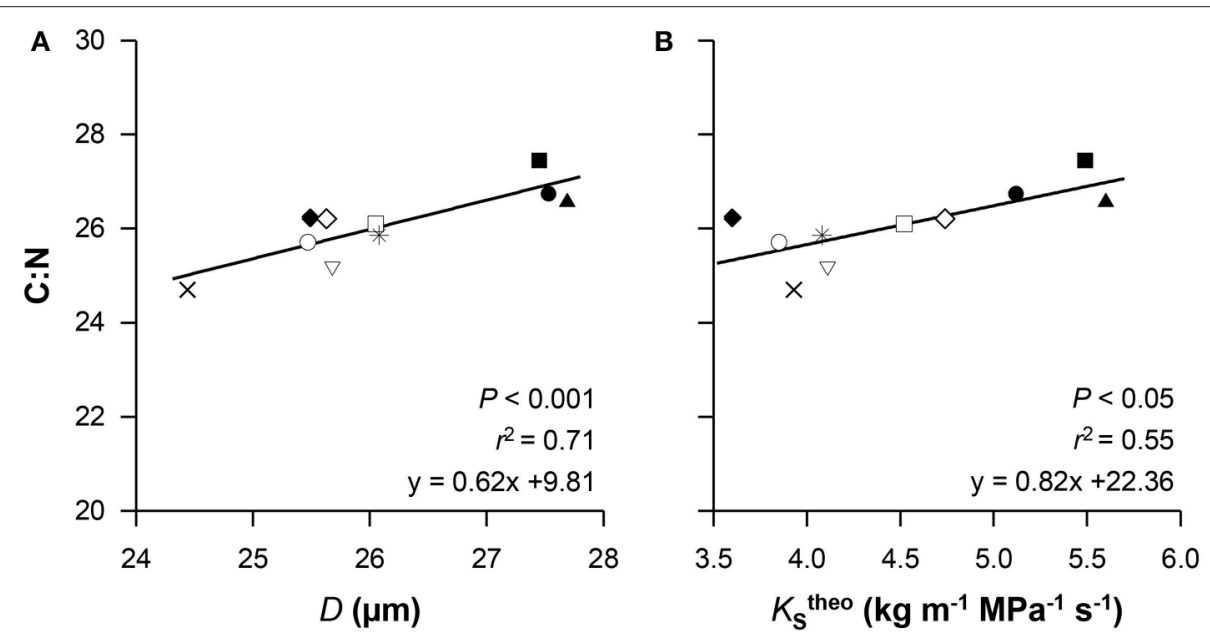

FIGURE 4 | The carbon to nitrogen ratio (C:N) in relation to vessel diameter $(\boldsymbol{D}, \mathrm{A})$ and theoretical specific conductivity $\left(\boldsymbol{K}_{\mathrm{S}}^{\text {theo }}, \mathrm{B}\right)$. Given values are means per provenance, for symbol definition see Figure 1. 
represent the most drought tolerant provenances in terms of functional trait adaptation as expected (see Eilmann et al., 2014). This finding is in agreement with former studies quantifying the high phenotypic plasticity of embolism resistance across environmental gradients (Herbette et al., 2010; Wortemann et al., 2011; Schuldt et al., 2016). Moreover, the vessel density of the branch xylem seems to play an outstanding role in the adaptation of the branch hydraulic system to different climates. Likewise with embolism resistance, vessel density varied independently of climatic conditions at the place of origin but was significantly different among provenances presumably as a consequence of differences in branch height. European beech trees may accordingly hold the capacity to adapt to local climate conditions by modifying their branch hydraulic traits primarily through adjustments in the relative abundance of vessels. This assumption is further supported by the close relation between vessel density and productivity as tree growth performance is hypothesized to scale with hydraulic efficiency (Tyree, 2003), which contrary to our results has been confirmed for both temperate and tropical tree species (Hajek et al., 2014; Hoeber et al., 2014; Kotowska et al., 2015).

\section{Functional Trade-Offs}

It has been suggested that embolism resistance decreases with growth rate due to conflicting carbon allocation either to the construction of thicker cell walls, or to the building of foliar and axial tissues destined to increase canopy carbon gain (Cochard et al., 2007). However, empirical data from different species or genotypes do not unequivocally support this trade-off. For example, Fichot et al. (2010) reported on embolism-resistant genotypes of poplar which grew faster than more vulnerable genotypes. We observed no relation between $P_{50}$ in branches and aboveground biomass increment across the provenances contradicting the hypothesized relation between embolism resistance and growth, which should trade-off with hydraulic efficiency. Several recent studies also failed to detect this relationship between embolism resistance and growth rate (Sterck et al., 2012; Hajek et al., 2014; Guet et al., 2015), indicating that embolism resistance is partly decoupled from hydraulic efficiency and biomass production (Fichot et al., 2015). In agreement hereon and in line with our results, hydraulic safety seems mostly decoupled from hydraulic efficiency, both at the inter-specific (Gleason et al., 2016) and intra-specific level (Schuldt et al., 2016; but see Hajek et al., 2014). In addition to these anticipated trade-offs it is necessary to include the foliage functionality for a holistic understanding of growthrelated processes (Carlquist, 2012). In our sample, the $P_{50}$ and $P_{88}$ values decreased in parallel with increasing carbon isotope signature. The most embolism resistant provenances thus presumably had to close their stomata more frequently at the expense of significantly reduced carbon assimilation. This observation is contradicting observations of the functional coordination between vulnerability to xylem cavitation and the regulation of stomatal conductance (Sparks and Black, 1999; Brodribb et al., 2002). Either a sensitive stomatal regulation or simply a lower water demand as a consequence of smaller stature of drought prone provenances may explain this trait interrelation.

Moreover, the $P_{50}$ and $P_{88}$ values were not related to xylem anatomical traits like vessel diameter or vessel density as evidenced in several studies among and across species (Domec et al., 2010; Hajek et al., 2014). In contrast, the range of variation was small in our study and might have hampered a significant relationship as likewise described by other authors who also failed to detect a relation between vessel diameter and embolism resistance in closely related genotypes or different hybrids of poplar (Cochard et al., 2007; Fichot et al., 2010). These findings support the growing evidence that variation in $P_{50}$ is mainly determined by other wood structural properties such as the topology of the xylem network (Loepfe et al., 2007; MartínezVilalta et al., 2012) as well as the pit membrane morphology (Plavcova et al., 2013; Li et al., 2016). The relation with vessel size in studies covering a sufficiently steep range in diameters is thus rather indirect as already speculated by Tyree and Sperry (1989).

In our study, provenances originating from drought-prone habitats (e.g., Spain) were most vulnerable to xylem cavitation. This contradicts the general observation of a less vulnerable structure for provenances originating from drought-prone sites (Rose et al., 2009; Robson et al., 2012). Surprisingly, the Spanish provenance developed the largest vessels of all ten provenances under these favorable environmental conditions contrary to our expectation. Due to the genetic control of this trait, beech provenances adapted to drier climates seem to over-develop their vascular system when grown in more humid environments. However, this did not translate into a better growth performance of these provenances.

\section{CONCLUSION}

Our study on ten beech provenances from all over Europe revealed that most wood anatomical and derived hydraulic traits and some foliar traits are under genetic predisposition according to significant differentiation between provenances or the relation with climatic aridity at the place of provenance origin. Although a certain degree of genetic differentiation was observed for embolism resistance, the high ratio of intra- vs. inter-population variance suggests that the genotypic variability of this trait is high between genotypes of a given provenance. In European beech, this high adaptive capacity in xylem function seems predominantly to be a consequence of adjusting vessel number but not necessarily vessel size. Nevertheless, we could not confirm the anticipated trade-off between hydraulic efficiency, xylem safety and growth in agreement with several recent studies. It further remains unclear if the observed high adaptive capacity of young European beech tree individuals can be extrapolated to old-growth forest trees, potentially enabling them to withstand increased drought by a flexible hydraulic response.

\section{AUTHOR CONTRIBUTIONS}

BS and GvW designed the study, PH, DK, and BS collected the field samples, DK and $\mathrm{PH}$ performed the hydraulic, wood 
anatomical and leaf morphological measurements and $\mathrm{PH}, \mathrm{BS}$, and SD analyzed the data and performed the statistical analyses. $\mathrm{PH}$ and BS wrote the first version of the manuscript, which was intensively discussed and revised by all authors.

\section{ACKNOWLEDGMENTS}

We thank Roman Link for statistical advice, Ana Sapoznikova and all other assistants for their invaluable contributions to the experiment and the two reviewers, who provided helpful suggestions for improving the manuscript. The

\section{REFERENCES}

Anderegg, W. R. L., and Meinzer, F. C. (2015). "Wood anatomy and plant hydraulics in a changing climate," in Functional and Ecological Xylem Anatomy, ed U. Hacke (Berlin: Springer International Publishing), 235-253.

Aranda, I., Cano, F. J., Gasco, A., Cochard, H., Nardini, A., Mancha, J. A., et al. (2015). Variation in photosynthetic performance and hydraulic architecture across European beech (Fagus sylvatica L.) populations supports the case for local adaptation to water stress. Tree Physiol. 35, 34-46. doi: 10.1093/treephys/tpu101

Bergel, D. (1973). Formzahluntersuchungen an Buche, Fichte, europäischer Lärche und japanischer Lärche zur Aufstellung neuer Massentafeln. Allg Forst-U Jagdztg 144, 117-124.

Bolte, A., Czajkowski, T., and Kompa, T. (2007). The north-eastern distribution range of European beech-a review. Forestry 80, 413-429. doi: 10.1093/forestry/cpm028

Bréda, N., Huc, R., Granier, A., and Dreyer, E. (2006). Temperate forest trees and stands under severe drought: a review of ecophysiological responses, adaptation processes and long-term consequences. Ann. For. Sci. 63, 625-644. doi: 10.1051/forest:2006042

Bresson, C. C., Vitasse, Y., Kremer, A., and Delzon, S. (2011). To what extent is altitudinal variation of functional traits driven by genetic adaptation in European oak and beech? Tree Physiol. 31, 1164-1174. doi: 10.1093/treephys/tpr084

Brodribb, T. J., Holbrook, N. M., and Gutiérrez, M. V. (2002). Hydraulic and photosynthetic co-ordination in seasonally dry tropical forest trees. Plant Cell Environ. 25, 1435-1444. doi: 10.1046/j.1365-3040.2002.00919.x

Carlquist, S. (2012). How wood evolves: a new synthesis. Botany 90, 901-940. doi: 10.1139/b2012-048

Cochard, H., Casella, E., and Mencuccini, M. (2007). Xylem vulnerability to cavitation varies among poplar and willow clones and correlates with yield. Tree Physiol. 27, 1761-1767. doi: 10.1093/treephys/27.12.1761

Cochard, H., Damour, G., Bodet, C., Tharwat, I., Poirier, M., and Améglio, T. (2005). Evaluation of a new centrifuge technique for rapid generation of xylem vulnerability curves. Physiol. Plant 124, 410-418. doi: 10.1111/j.13993054.2005.00526.x

Domec, J.-C., Schäfer, K., Oren, R., Kim, H. S., and McCarthy, H. R. (2010). Variable conductivity and embolism in roots and branches of four contrasting tree species and their impacts on whole-plant hydraulic performance under future atmospheric CO2 concentration. Tree Physiol. 30, 1001-1015. doi: 10.1093/treephys/tpq054

Eilmann, B., Sterck, F., Wegner, L., de Vries, S. M., von Arx, G., Mohren, G. M., et al. (2014). Wood structural differences between northern and southern beech provenances growing at a moderate site. Tree Physiol. 34, 882-893. doi: 10.1093/treephys/tpu069

Ellenberg, H., and Leuschner, C. (2010). Vegetation Mitteleuropas mit den Alpen in Ökologischer, Dynamischer und Historischer Sicht. 6th Edn. Stuttgart: Ulmer.

Fichot, R., Barigah, T. S., Chamaillard, S., Le Thiec, D., Laurans, F., Cochard, H., et al. (2010). Common trade-offs between xylem resistance to cavitation and other physiological traits do not hold among unrelated Populus deltoides $\times$ Populus nigra hybrids. Plant Cell Environ. 33, 1553-1568. doi: 10.1111/j.13653040.2010.02164.x work has been financially supported by the University of Göttingen granted to BS. We further acknowledge the support by the Open Access Publication Funds of the University of Göttingen.

\section{SUPPLEMENTARY MATERIAL}

The Supplementary Material for this article can be found online at: http://journal.frontiersin.org/article/10.3389/fpls.2016. 00791

Fichot, R., Brignolas, F., Cochard, H., and Ceulemans, R. (2015). Vulnerability to drought-induced cavitation in poplars: synthesis and future opportunities. Plant Cell Environ. 38, 1233-1251. doi: 10.1111/pce.12491

Fuehrer, E., Horváth, L., Jagodics, A., Machon, A., and Szabados, I. (2011). Application of new aridity index in Hungarian forestry practice. Q. J. Hung. Meteorol. Serv. 115, 205-216.

Gleason, S. M., Westoby, M., Jansen, S., Choat, B., Hacke, U. G., Pratt, R. B., et al. (2016). Weak tradeoff between xylem safety and xylem-specific hydraulic efficiency across the world's woody plant species. New Phytol. 209, 123-136. doi: 10.1111/nph.13646

Guet, J., Fichot, R., Lédée, C., Laurans, F., Cochard, H., Delzon, S., et al. (2015). Stem xylem resistance to cavitation is related to xylem structure but not to growth and water-use efficiency at the within-population level in Populus nigra L. J. Exp. Bot. 66, 4643-4652. doi: 10.1093/jxb/erv232

Hajek, P., Leuschner, C., Hertel, D., Delzon, S., and Schuldt, B. (2014). Trade-offs between xylem hydraulic properties, wood anatomy and yield in Populus. Tree Physiol. 34, 744-756. doi: 10.1093/treephys/tpu048

Hamrick, J. (2004). Response of forest trees to global environmental changes. For. Ecol. Manag. 197, 323-335. doi: 10.1016/j.foreco.2004.05.023

Herbette, S., Wortemann, R., Awad, H., Huc, R., Cochard, H., and Barigah, T. S. (2010). Insights into xylem vulnerability to cavitation in Fagus sylvatica L.: phenotypic and environmental sources of variability. Tree Physiol. 30, 1448-1455. doi: 10.1093/treephys/tpq079

Hijmans, R. J., Cameron, S. E., Parra, J. L., Jones, P. G., Jarvis, A., and others (2005). Very high resolution interpolated climate surfaces for global land areas. Int. J. Climatol. 25, 1965-1978. doi: 10.1002/joc.1276

Hoeber, S., Leuschner, C., Köhler, L., Arias-Aguilar, D., and Schuldt, B. (2014). The importance of hydraulic conductivity and wood density to growth performance in eight tree species from a tropical semi-dry climate. For. Ecol. Manag. 330, 126-136. doi: 10.1016/j.foreco.2014.06.039

Jump, A. S., Hunt, J. M., and Peñuelas, J. (2006). Rapid climate change-related growth decline at the southern range edge of Fagus sylvatica. Glob. Change Biol. 12, 2163-2174. doi: 10.1111/j.1365-2486.2006.01250.x

Kahle, H. P. (2006). "Impact of the drought in 2003 on intra-and inter-annual stem radial growth of beech and spruce along an altitudinal gradient in the Black Forest, Germany," in TRACE-Tree Rings in Archaeology, Climatology and Ecology, Vol. 4: Proceedings of the Dendrosymposium 2005, eds H. I. Gärtner, M. Monbaron, and G. Schleser (Fribourg: Forschungszentrums Jülich), 152-164. Schriften des Forschungszentrums Jülich, Reihe Umwelt Vol. 61.

Kotowska, M. M., Hertel, D., Rajab, Y. A., Barus, H., and Schuldt, B. (2015). Patterns in hydraulic architecture from roots to branches in six tropical tree species from cacao agroforestry and their relation to wood density and stem growth. Front. Plant Sci. 6:191. doi: 10.3389/fpls.2015.00191

Kremer, A., Potts, B. M., and Delzon, S. (2014). Genetic divergence in forest trees: understanding the consequences of climate change. Funct. Ecol. 28, 22-36. doi: 10.1111/1365-2435.12169

Lamy, J.-B., Bouffier, L., Burlett, R., Plomion, C., Cochard, H., and Delzon, S. (2011). Uniform selection as a primary force reducing population genetic differentiation of cavitation resistance across a species range. PLOS ONE 6:e23476. doi: 10.1371/journal.pone.0023476

Lamy, J.-B., Delzon, S., Bouche, P. S., Alia, R., Vendramin, G. G., Cochard, H., et al. (2014). Limited genetic variability and phenotypic plasticity detected for 
cavitation resistance in a Mediterranean pine. New Phytol. 201, 874-886. doi: 10.1111/nph.12556

Leuschner, C., Backes, K., Hertel, D., Schipka, F., Schmitt, U., Terborg, O., et al. (2001). Drought responses at leaf, stem and fine root levels of competitive Fagus sylvatica L. and Quercus petraea (Matt.) Liebl. trees in dry and wet years. For. Ecol. Manag. 149, 33-46. doi: 10.1016/S0378-1127(00)00543-0

Leuzinger, S., Zotz, G., Asshoff, R., and Körner, C. (2005). Responses of deciduous forest trees to severe drought in Central Europe. Tree Physiol. 25, 641-650. doi: 10.1093/treephys/25.6.641

Lewis, A. M., and Boose, E. R. (1995). Estimating volume flow rates through xylem conduits. Am. J. Bot. 82, 1112-1116. doi: 10.2307/2446063

Li, S., Feifel, M., Karimi, Z., Schuldt, B., Choat, B., and Jansen, S. (2015). Leaf gas exchange performance and the lethal water potential of five European species during drought. Tree Physiol. 36, 179-192. doi: 10.1093/treephys/ tpv117

Li, S., Lens, F., Espino, S., Karimi, Z., Klepsch, M., Schenk, J., et al. (2016). Intervessel pit membrane thickness as a key determinant of embolism resistance in angiosperm xylem. IAWA J. 37, 152-171. doi: 10.1163/2294193220160128

Lindner, M., Maroschek, M., Netherer, S., Kremer, A., Barbati, A., GarciaGonzalo, J., et al. (2010). Climate change impacts, adaptive capacity, and vulnerability of European forest ecosystems. For. Ecol. Manage. 259, 698-709. doi: 10.1016/j.foreco.2009.09.023

Loepfe, L., Martinez-Vilalta, J., Piñol, J., and Mencuccini, M. (2007). The relevance of xylem network structure for plant hydraulic efficiency and safety. J. Theor. Biol. 247, 788-803. doi: 10.1016/j.jtbi.2007.03.036

Martínez-Vilalta, J., Mencuccini, M., Álvarez, X., Camacho, J., Loepfe, L., and Piñol, J. (2012). Spatial distribution and packing of xylem conduits. Am. J. Bot. 99, 1189-1196. doi: 10.3732/ajb.1100384

Peuke, A. D., Schraml, C., Hartung, W., and Rennenberg, H. (2002). Identification of drought-sensitive beech ecotypes by physiological parameters. New Phytol. 154, 373-387. doi: 10.1046/j.1469-8137.2002.00400.x

Plavcova, L., Jansen, S., Klepsch, M., and Hacke, U. G. (2013). Nobody's perfect: can irregularities in pit structure influence vulnerability to cavitation? Front. Plant Sci. 4:453. doi: 10.3389/fpls.2013.00453

R Development Core Team (2011). R: A Language and Environment for Statistical Computing. Vienna, Austria: R Foundation for Statistical Computing. Available onlie at: http://www.R-project.org

Robson, T. M., Sánchez-Gómez, D., Cano, F. J., and Aranda, I. (2012). Variation in functional leaf traits among beech provenances during a Spanish summer reflects the differences in their origin. Tree Genet. Genomes 8, 1111-1121. doi: 10.1007/s11295-012-0496-5

Rose, L., Leuschner, C., Köckemann, B., and Buschmann, H. (2009). Are marginal beech (Fagus sylvatica L.) provenances a source for drought tolerant ecotypes? Eur. J. For. Res. 128, 335-343. doi: 10.1007/s10342-0090268-4

Sáenz-Romero, C., Lamy, J.-B., Loya-Rebollar, E., Plaza-Aguilar, A., Burlett, R., Lobit, P., et al. (2013). Genetic variation of drought-induced cavitation resistance among Pinus hartwegii populations from an altitudinal gradient. Acta Physiol. Plant 35, 2905-2913. doi: 10.1007/s11738-013$1321-y$

Schreiber, S. G., Hacke, U. G., and Hamann, A. (2015). Variation of xylem vessel diameters across a climate gradient: insight from a reciprocal transplant experiment with a widespread boreal tree. Funct. Ecol. 29, 1392-1401. doi: $10.1111 / 1365-2435.12455$

Schuldt, B., Knutzen, F., Delzon, S., Jansen, S., Müller-Haubold, H., Burlett, R., et al. (2016). How adaptable is the hydraulic system of European beech in the face of climate change related precipitation reduction? New Phytol. 210, 443-458. doi: 10.1111/nph.13798

Sparks, J. P., and Black, R. A. (1999). Regulation of water loss in populations of Populus trichocarpa: the role of stomatal control in preventing xylem cavitation. Tree Physiol. 19, 453-459. doi: 10.1093/treephys/19.7.453
Sperry, J. S., Nichols, K. L., Sullivan, J. E. M., and Eastlack, S. E. (1994). Xylem embolism in ring-porous, diffuse-porous, and coniferous trees of Northern Utah and Interior Alaska. Ecology 75, 1736-1752. doi: 10.2307/1939633

Sterck, F. J., Martínez-Vilalta, J., Mencuccini, M., Cochard, H., Gerrits, P., Zweifel, R., et al. (2012). Understanding trait interactions and their impacts on growth in Scots pine branches across Europe. Funct. Ecol. 26, 541-549. doi: 10.1111/j.1365-2435.2012.01963.x

Stojnić, S., Orlović, S., Miljković, D., Galić, Z., Kebert, M., and von Wuehlisch, G. (2015). Provenance plasticity of European beech leaf traits under differing environmental conditions at two Serbian common garden sites. Eur. J. For. Res. 134, 1109-1125. doi: 10.1007/s10342-015-0914-y

Tyree, M. T. (2003). Hydraulic limits on tree performance: transpiration, carbon gain and growth of trees. Trees 17, 95-100. doi: 10.1007/s00468-002-0227-x

Tyree, M. T., and Sperry, J. S. (1989). Vulnerability of xylem to cavitation and embolism. Annu. Rev. Plant Physiol. Plant Mol. Biol. 40, 19-36. doi: 10.1146/annurev.pp.40.060189.000315

Urli, M., Porté, A. J., Cochard, H., Guengant, Y., Burlett, R., and Delzon, S. (2013). Xylem embolism threshold for catastrophic hydraulic failure in angiosperm trees. Tree Physiol. 33, 672-683. doi: 10.1093/treephys/tpt030

van der Werf, G. W., Sass-Klaassen, U. G. W., and Mohren, G. M. J. (2007). The impact of the 2003 summer drought on the intra-annual growth pattern of beech (Fagus sylvatica L.) and oak (Quercus robur L.) on a dry site in the Netherlands. Dendrochronologia 25, 103-112. doi: 10.1016/j.dendro.2007.03.004

Verbeke, G., and Molenberghs, G. (2009). Linear Mixed Models for Longitudinal Data. New York, NY: Springer.

von Wuehlisch, G., Liesebach, M., Muhs, H. J., and Stephan, R. (1998). “A network of international beech provenance trials," in First EUFORGEN Meeting on Social Broadleaves, 23-25 October 1997, Bordeaux, France, eds J. Turok, A. Kremer, and S. De Vries (Rome: International Plant Genetic Resources Institute), 164-172.

Willigen, C. V., and Pammenter, N. W. (1998). Relationship between growth and xylem hydraulic characteristics of clones of Eucalyptus spp. at contrasting sites. Tree Physiol. 18, 595-600. doi: 10.1093/treephys/18.8-9.595

Wortemann, R., Herbette, S., Barigah, T. S., Fumanal, B., Alia, R., Ducousso, A., et al. (2011). Genotypic variability and phenotypic plasticity of cavitation resistance in Fagus sylvatica L. across Europe. Tree Physiol. 31, 1175-1182. doi: 10.1093/treephys/tpr101

Wutzler, T., Wirth, C., and Schumacher, J. (2008). Generic biomass functions for Common beech (Fagus sylvatica) in Central Europe: predictions and components of uncertainty. Can. J. For. Res. 38, 1661-1675. doi: 10.1139/X07194

Zimmermann, J., Hauck, M., Dulamsuren, C. and Leuschner, C. (2015). Climate warming-related growth decline affects Fagus sylvatica, but not other broadleaved tree species in Central European mixed forests. Ecosystems 1, 560-572. doi: 10.1007/s10021-015-9849-x

Zomer, R. J., Trabucco, A., Bossio, D. A., and Verchot, L. V. (2008). Climate change mitigation: a spatial analysis of global land suitability for clean development mechanism afforestation and reforestation. Agric. Ecosyst. Environ. 126, 67-80. doi: 10.1016/j.agee.2008.01.014

Conflict of Interest Statement: The authors declare that the research was conducted in the absence of any commercial or financial relationships that could be construed as a potential conflict of interest.

Copyright (c) 2016 Hajek, Kurjak, von Wühlisch, Delzon and Schuldt. This is an open-access article distributed under the terms of the Creative Commons Attribution License (CC BY). The use, distribution or reproduction in other forums is permitted, provided the original author(s) or licensor are credited and that the original publication in this journal is cited, in accordance with accepted academic practice. No use, distribution or reproduction is permitted which does not comply with these terms. 